\title{
Systematic lidar observations of Saharan dust layers over Athens, Greece in the frame of EARLINET project (2004-2006)
}

\author{
A. Papayannis ${ }^{1}$, R. E. Mamouri ${ }^{1}$, V. Amiridis ${ }^{2}$, S. Kazadzis $^{3,4}$, C. Pérez ${ }^{5}$, G. Tsaknakis ${ }^{1}$, P. Kokkalis ${ }^{1}$, and \\ J. M. Baldasano $0^{5,6}$ \\ ${ }^{1}$ Physics Department, National Technical University of Athens, Athens, Greece \\ ${ }^{2}$ Institute for Space Applications and Remote Sensing, National Observatory of Athens, Athens, Greece \\ ${ }^{3}$ Finnish Meteorological Institute, Climate Change group, Helsinki, Finland \\ ${ }^{4}$ Institute of Environmental Research and Sustainable Development, National Observatory of Athens, Greece \\ ${ }^{5}$ Barcelona Supercomputing Center - Centro Nacional de Supercomputación (BSC-CNS), Earth Sciences Division, \\ Barcelona, Spain \\ ${ }^{6}$ Environmental Modeling Laboratory, Project Engineering Dept., Universidad Politécnica de Cataluña, Barcelona, Spain
}

Received: 27 March 2009 - Revised: 20 July 2009 - Accepted: 9 September 2009 - Published: 29 September 2009

\begin{abstract}
In this paper we present a statistical analysis on the geometrical and optical properties of Saharan dust layers observed over Athens, Greece, in a three-year period from 1 January 2004 up to 31 December 2006. The observations of the vertical aerosol profile were performed by the multi-wavelength (355-532-1064-387-607 nm) Raman lidar system of the National Technical University of Athens (NTUA) operated in the city of Athens $\left(37^{\circ} 98^{\prime} \mathrm{N}, 23^{\circ} 77^{\prime} \mathrm{E}\right)$, Greece, in the frame of the European Aerosol Research Lidar Network (EARLINET-ASOS) project. The number of dust events was greatest in late spring, summer, and early autumn periods. This was evident also by aerosol observations during dust outbreaks obtained from the Moderate Resolution Imaging Spectroradiometer (MODIS). In our lidar measurements, multiple aerosol dust layers of variable thickness (680-4800 m) were observed. The center of mass of these layers was located in altitudes between 1600 and $5800 \mathrm{~m}$. However, the mean thickness of the dust layer typically stayed around $2700 \mathrm{~m}$ and the corresponding mean center of mass was of the order of $2900 \mathrm{~m}$. The top of the dust layer ranged from 2000 to $8000 \mathrm{~m}$, with a mean value of the order of $4700 \mathrm{~m}$. MODIS observations during dust outbreaks showed that the AOD values at $550 \mathrm{~nm}$ ranged between $0.3-$ 0.6, while the corresponding Angström exponent (AE) values were of the order of $0.5-0.65$, indicating the presence of rather large particles.
\end{abstract}

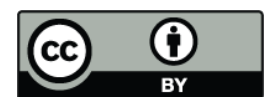

Correspondence to: A. Papayannis (apdlidar@central.ntua.gr)
Keywords. Atmospheric composition and structure (Aerosols and particles)

\section{Introduction}

Aerosols, are very important constituents of the atmosphere. They scatter and absorb solar and terrestrial radiation (direct effect) and alter the physical, optical, and lifetime properties of clouds and thus the precipitation formation (indirect effect), as they act as cloud condensation nuclei (Levin et al., 1996; Sokolik and Toon, 1999; Rosenfeld et al., 2001; Kaufman et al., 2002; Teller and Levin, 2006; Hatzianastasiou et al., 2007; Haywood et al., 2008; Johnson et al., 2008).

According to the latest report of the Intergovernmental Panel on Climate Change (IPCC) (Forster et al., 2007), the climatic role of dust aerosols is now better quantified than in the past, thus, a total direct aerosol radiative forcing, combined across all aerosol types, can now be given as $-0.5 \pm 0.4 \mathrm{~W} / \mathrm{m}^{2}$, with a medium-low level of scientific understanding. However, the overall uncertainties in the radiative forcing effect of dust (anthropogenic and natural) remain still very high. These uncertainties can only be reduced by better quantifying the vertical and horizontal distribution of dust in the globe. Lidar aerosol measurements of the vertical distribution of the optical properties of dust can contribute to such quantification.

Mineral dust is an important component of the atmospheric aerosol loading. According to Kinne et al. (2006) mineral dust accounts for about $75 \%$ of the global aerosol

Published by Copernicus Publications on behalf of the European Geosciences Union. 
mass load and $25 \%$ of the global aerosol optical depth. The African continent, especially its northern part (Sahara desert), the Saudi Arabian regions, as well as the Asian continent (eastern areas), are the main sources of dust around the globe (Duce, 1995; Marticorena et al., 1997; Prospero et al., 2002; Engelstaedter and Washington, 2007).

Several operational dust forecasting models have been developed so far. These models include parameterizations for dust uplift, dust transport, and dust deposition and provide forecasting diagnostics such as aerosol optical depth (AOD) and/or dust load, dust surface concentration, as well as vertical profiles of dust concentration (Nickovic et al., 2001; Pérez et al., 2006; Menut et al., 2007; Greed et al., 2008; Laurent et al., 2008; Menut, 2008). These models have been validated across case study analyses over Europe-N. Africa and Asia, where it has been shown that they can provide very good forecast of dust events, several hours ahead (Menut et al., 2007; Papayannis et al., 2007; Greed et al., 2008; Jiménez-Guerrero et al., 2008).

Aerosols also influence the Earth's biogeochemical cycles (Jickells et al., 2005; Kaufman et al., 2005), while dust clouds have also a large impact on human health as they transport infectious micro-organisms to distances up to several thousands of km (Prospero, 1999; Molesworth et al., 2002; Sultan et al., 2005). For all the above-cited reasons there is a strong need for aerosol vertical profile monitoring over the globe, especially over sites closely spaced to important dust source regions.

Passive remote sensing of dust particles cannot document and characterize long-range transport of aerosols in the free troposphere, although some first results on long-term satellite observations of air pollution on the global-scale were reported by Husar et al. (1997). However, passive satellite sensors cannot distinguish between particles in the planetary boundary layer (PBL) and the free troposphere, thus, the retrieved parameters describe mostly a mixture of different aerosol types. On the other hand, active remote sensing (lidar technique) can retrieve the vertical profile of the optical and microphysical properties of the aerosol particles from the lower troposphere up to the upper mesosphere with high temporal and spatial resolution (Amiridis et al., 2005; Balis et al., 2006; Papayannis et al., 2007a, b; Mattis et al., 2008).

Systematic aerosol lidar measurements over Greece have started on May 2000 within the frame of the EARLINET project (Bösenberg et al., 2003). The works of Balis et al. (2004) and Balis et al. (2006) gave some first information on basic optical properties of dust particles over Greece in the Eastern Mediterranean region, as obtained by the analysis of lidar data obtained during case studies of specific dust outbreaks occurred over Greece. In addition, the works of Papayannis et al. (2005) and Amiridis et al. (2005) made possible, for the first time, the estimation of the vertical extent and optical properties of free tropospheric dust layers (mean values of the aerosol backscatter and extinction coefficients and the extinction-to-backscatter ratio (lidar ratio,
LR) at $355 \mathrm{~nm}$ ), as well as the seasonal distribution of Saharan dust outbreaks over two sites in Greece, under cloud-free conditions for a three to four years period: $2000-2002$ and 2001-2004, respectively.

In this paper we present a statistical analysis of the Sahara dust events observed over Athens, Greece, in a threeyear period from 1 January 2004 up to 31 December 2006. Due to major hardware lidar system upgrades the acquired data before 1 January 2004 are not fully compatible with those analyzed in this paper. Therefore, they cannot be taken into account as a homogeneous lidar data timeseries. Section 2 of this paper gives a brief presentation of the lidar measurements over Athens, as well as a brief description of the BSC Dust Regional Atmospheric Model (BSC/DREAM). It presents also the criteria applied to characterize an aerosol layer as dust layer and discuss the monthly averages of dust occurrences observed and forecasted over Athens. Section 3 focuses on the lidar data analysis, supported by satellite (MODIS: Moderate Resolution Imaging Spectroradiometer) aerosol observations, during dust events in the reported period. Finally, Sect. 4 presents our concluding remarks.

\section{Methodology and measurements}

\subsection{Lidar measurements over Athens within EARLINET}

The lidar system of the National Technical University of Athens (NTUA) is located at the NTUA campus in the city of Athens $\left(37.97^{\circ} \mathrm{N}, 23.79^{\circ} \mathrm{E}, 200 \mathrm{~m}\right.$ above sea level). It started performing systematic measurements in the frame of the EARLINET project (Bösenberg et al., 2003) on February 2000 , as an elastic backscatter lidar system to measure the vertical profiles of the aerosol backscatter coefficients at 355 and $532 \mathrm{~nm}$. Later, the system undertook major hardware upgrades (e.g. on mid-2001 addition of a Raman $\left(\mathrm{N}_{2}\right)$ channel at $387 \mathrm{~nm}$, redesign of the detection box and its optical components during the year 2003, late 2007 and early 2008 addition of a Raman $\left(\mathrm{N}_{2}\right)$ channel at $607 \mathrm{~nm}$, and finally on late 2008 use of new interference filters at 387 and $607 \mathrm{~nm}$ ) to provide, independently, the vertical profiles of the aerosol backscatter and extinction coefficients at both 355 and $532 \mathrm{~nm}$. Therefore the selected period of measurements (1 January 2004 up to 31 December 2006) provides homogeneous lidar data during a period of 3 full years. The NTUA lidar system has been quality-assured by performing direct intercomparisons, both at hardware and software levels (Böckmann et al., 2004; Matthias et al., 2004a; Pappalardo et al., 2004).

In order to get reliable and quantitative lidar aerosol data several techniques and methods have to be combined. For example, the standard backscatter lidar technique is appropriate to retrieve aerosol parameters mostly for small optical depths, as in clean areas, assuming a reference height in 
an aerosol-free area, as for example the upper troposphere. In this case, the Klett inversion technique is used to retrieve the vertical profile of the aerosol backscatter coefficient $\left(b_{\text {aer }}\right)$ at the respective wavelengths (Klett, 1985). The resulting average uncertainty on the retrieval of $b_{\text {aer }}$ (including both statistical and systematic errors and corresponding to $30-60 \mathrm{~min}$. temporal resolution) in the troposphere is of the order of 20-30\% (Bösenberg et al., 1997). To overcome this large uncertainty associated with this technique, the Raman $\mathrm{N}_{2}$ lidar technique was adopted and implemented, as discussed previously. Using the methodology proposed by Ansmann et al. (1992) the measurement of the elasticbackscatter signals at 355 and $532 \mathrm{~nm}$, as well as that of the $\mathrm{N}_{2}$ inelastic-backscatter signals at 387 and $607 \mathrm{~nm}$, permits the determination of the extinction $\left(a_{\mathrm{aer}}\right)$ and backscatter $\left(b_{\text {aer }}\right)$ coefficients independently of each other and, thus, of the extinction-to-backscatter ratio, the so-called lidar ratio (LR) at both wavelengths (355 and $532 \mathrm{~nm})$. Thus, the uncertainties of the retrieved $b_{\text {aer }}$ vertical profiles are of the order of 10-15\% (Mattis et al., 2002). The vertical profiles of $b_{\text {aer }}$ referring to measurements performed before the local sunset time $(\sim 19: 00 \mathrm{UT})$ were retrieved by using the Klett technique, assuming a lidar ratio value equal to $45 \mathrm{sr}$. This value is typical for a mixture of dust and marine aerosols at mid-latitudes (Papayannis et al., 2005). Since the Raman lidar signals have a very low intensity, the Raman lidar measurements are possible only during nighttime conditions.

According to the EARLINET protocol the lidar measurements are performed regularly three times per week: one around noon, when the PBL is well developed, and two within a time window of $1 \mathrm{~h}$ before and up to $3 \mathrm{~h}$ after the sunset. In addition, when Saharan dust conditions are forecasted, the measuring schedule is altered and additional lidar measurements are performed (Bösenberg et al., 2003). Sometimes, especially during the cold period (late autumnearly spring), weather conditions did not permit us to perform lidar measurements mostly due to the presence of low clouds or rain showers.

\subsection{The BSC/DREAM dust model}

The dust forecast is based on the operational outputs (aerosol dust load) of the BSC/DREAM (operated in Barcelona, Spain: http://www.bsc.es/projects/earthscience/ DREAM/) model (Nickovic et al., 2001). The model simulates or predicts the 3-dimensional field of the dust concentration in the troposphere. The dust model takes into account all major processes of dust life cycle, such as dust production, horizontal and vertical diffusion and advection and wet and dry deposition. The model also includes the effects of the particle size distribution on aerosol dispersion. In this version of the model the dust mass is described by particles with four sizes, resulting from the structure of desert soils based on the content of clay, small silt, large silt and sand. The model numerically solves the Euler-type mass par- tial differential equation by integrating it spatially and temporally. The dust production is parameterized using nearsurface turbulence and stability, as well as soil features. The dust production mechanism is on based Shao et al. (1993), viscous/turbulent mixing close to the surface and soil moisture content. The resolution of the model is set to $50 \mathrm{~km}$ in the horizontal and to $15 \mathrm{~km}$ in the vertical. Recently, BSC/DREAM was coupled to the combined photochemical forecast MM5-EMEP-CMAQ modelling system to provide an integrated air quality model with remarkable improvement in the discrete and skill-scores evaluation of $\mathrm{PM}_{10}$ exceedances in the Iberian Peninsula (Jiménez-Guerrero et al., 2008).

\subsection{The MODIS instrument}

The Moderate Resolution Imaging Spectroradiometer (MODIS) was launched in December 1999 on the polar orbiting Terra spacecraft and since February 2000 has been acquiring daily global data in 36 spectral bands from the visible to the thermal infrared (29 spectral bands with $1 \mathrm{~km}, 5$ spectral bands with $500 \mathrm{~m}$, and 2 with $250 \mathrm{~m}$, nadir pixel dimensions). The MODIS aerosol products are only created for cloud-free regions. The atmospheric optical depth (AOD) values are retrieved by MODIS at $550 \mathrm{~nm}$ for both ocean (best) and land (corrected) as described by the MODIS sensor website (http://modis-atmos.gsfc.nasa.gov/products.html). Kaufman and Tanré (1998) suggested that 1 standard deviation of retrievals would fall within $\pm(0.03+0.05 \mathrm{t})$ over ocean and $\pm(0.05+0.15 \mathrm{t})$ over land, where $\mathrm{t}$ is AOD. These error bounds, derived pre-launch are referred to as the "expected error." Several MODIS validation studies have been performed, during pre-launch and post-launch procedures regarding the aerosol optical properties such AOD measurements using ground-based instrumentation (Chu et al., 2002, 2003; Eck et al., 2003; Misra et al., 2008; Prasad and Singh, 2009).

\subsection{Dust events occurrences}

A set of three criteria has been applied to characterize the aerosol lidar data as "Saharan dust" profiles following the directions given by Papayannis et al. (2008): a) presence of a distinct aerosol dust layer using the first derivative of the lidar signal as in Menut et al. (1999), b) aerosol layer's origin is the Saharan region and c) forecast by the BSC/DREAM model. Following those criteria over 3 years of regular and special measurements, we identified aerosol layers related to Saharan dust outbreaks for a total of 79 days. The relative monthly distribution of the number of observed dust days is presented in Fig. 1 (hatched columns). We see that two relative maxima are observed in May and September, while the larger number of Saharan dust observations is found in the April-September period (Fig. 1). The low number of dust 


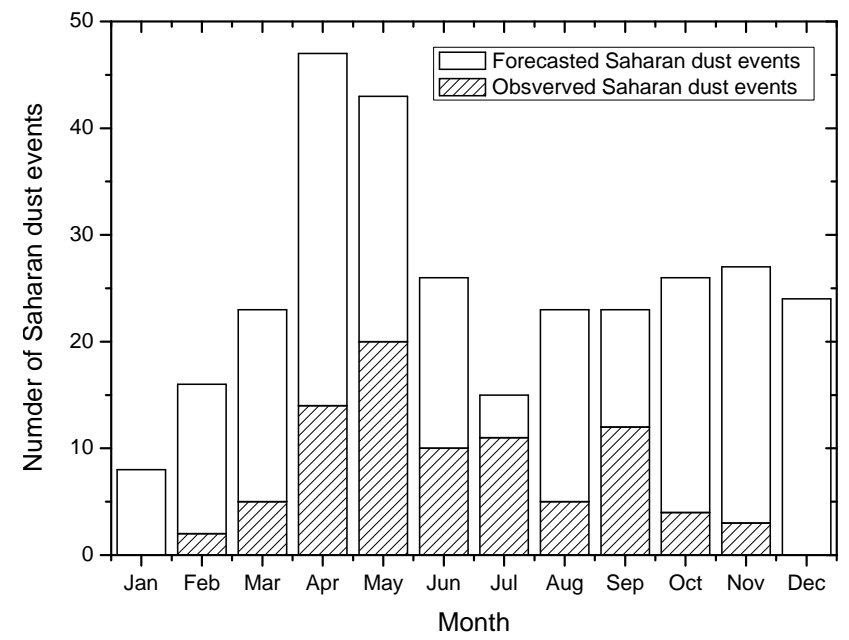

Fig. 1. Number of days per month in which Saharan dust intrusions are forecasted and observed over Athens during 3 years of lidar measurements (January 2004-December 2006).

intrusions during the cold period (October-March) can be related to the low dust emission over the Saharan region typical of this period (Marticorena et al., 1997), the possible aerosol wash-out during their way to Europe and to the strong seasonal behaviour of the dust transport in the Mediterranean area (Prospero et al., 2002; Papayannis et al., 2008).

Additionally, using the BSC/DREAM forecast model a large number of forecasted dust events was produced. However, in this paper we considered as "model-forecast" dust days, those for which the dust loading from BSC/DREAM was greater than $0.05 \mathrm{~g} / \mathrm{m}^{2}$. In this way 307 model-forecast dust days were found in total over our site (Fig. 1, white columns) during the reported period. The under-sampling of the dust events by the lidar observations with respect to the "model-forecast" days could be explained by the fact that lidar measurements could not be taken when unfavourable meteorological conditions prevailed (low-lying overcast or rainy conditions) over a specific measuring site or when technical problems occurred to the lidar system. Using the forecasted dust days (white column) we find that the spring, summer (except July) and autumn months are mainly influenced by the dust transport over Athens.

However, we decided to consider for our statistical analysis only those dust events over our site, for which the forecasted total dust load was higher than $1.0 \mathrm{~g} / \mathrm{m}^{2}$ (equivalent to $\mathrm{AOD}>0.5$ at $550 \mathrm{~nm}$ ). This threshold was set to discriminate between small and moderate to strong dust events, in consistency with dust models and previous observations (Tegen, 2003; Kaskaoutis et al., 2007; Papayannis et al., 2007a; Greed et al., 2008). In that way we selected to analyze the aerosol lidar measurements only for the strong dust days. Using this criterion we limited our aerosol vertical profiles to 40 out of the 79 available days. This is shown in Fig. 2 where the seasonal distribution of the strong dust events is given, as

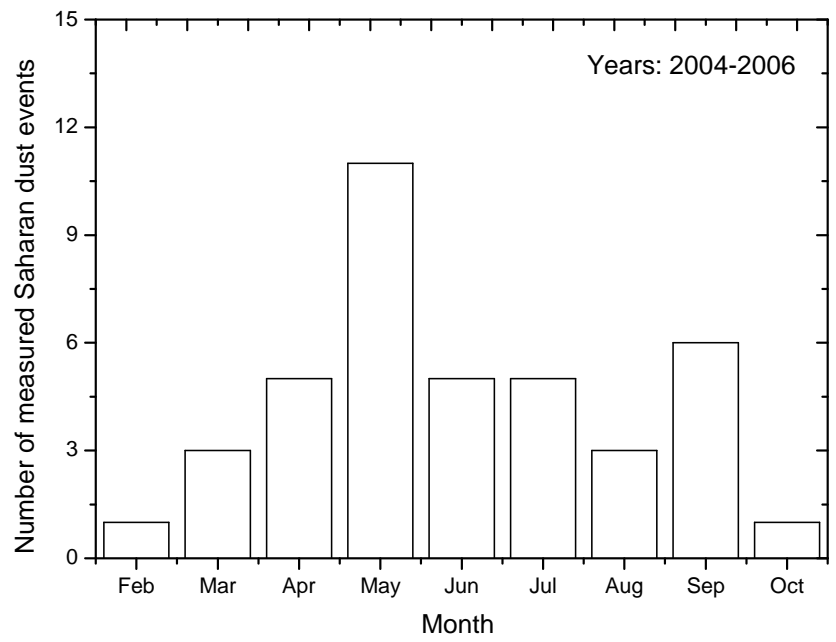

Fig. 2. Number of days per month in which strong Saharan dust intrusions are observed over Athens during 3 years of lidar measurements (January 2004-December 2006).

observed over our site. From that figure we see that two maxima are observed: one in May and one in September. For the rest of the months, the observed number of dust events follows a nearly Gaussian distribution, centred around June.

Ancillary observations to locate the Saharan dust plume over a measuring site included satellite aerosol-related data [aerosol load from MODIS (Moderate Resolution Imaging Spectroradiometer) and real-color pictures from the SeaWiFS (Sea-viewing Wide Field-of-view Sensor) sensors] for mutual comparison with the aerosol data from dust forecast models were used. Cloud screening (water or ice clouds) is performed prior to the storage of the data into the central database.

\section{Results and discussion}

In this section we will focus on the statistical analysis of the vertical aerosol profiles during Saharan dust events concerning the aerosol dust layering and the integrated backscatter values. Further on we will discuss on the temporal evolution of AOD and the Angström exponent (AE) values obtained from MODIS satellite observations during the reported period (January 2004-December 2006).

\subsection{Aerosol dust layers' characteristics}

When the lidar technique is applied to characterize the aerosol vertical profile during a dust event, the following layer properties can be derived from the aerosol backscatter profile: the top $\left(z_{t}\right)$, base $\left(z_{b}\right)$, layer thickness and centre of mass, following the procedure proposed by Mona et al. (2006). Thus, the base of the dust aerosol layer corresponds to the lowest point of a strong increase in the aerosol 


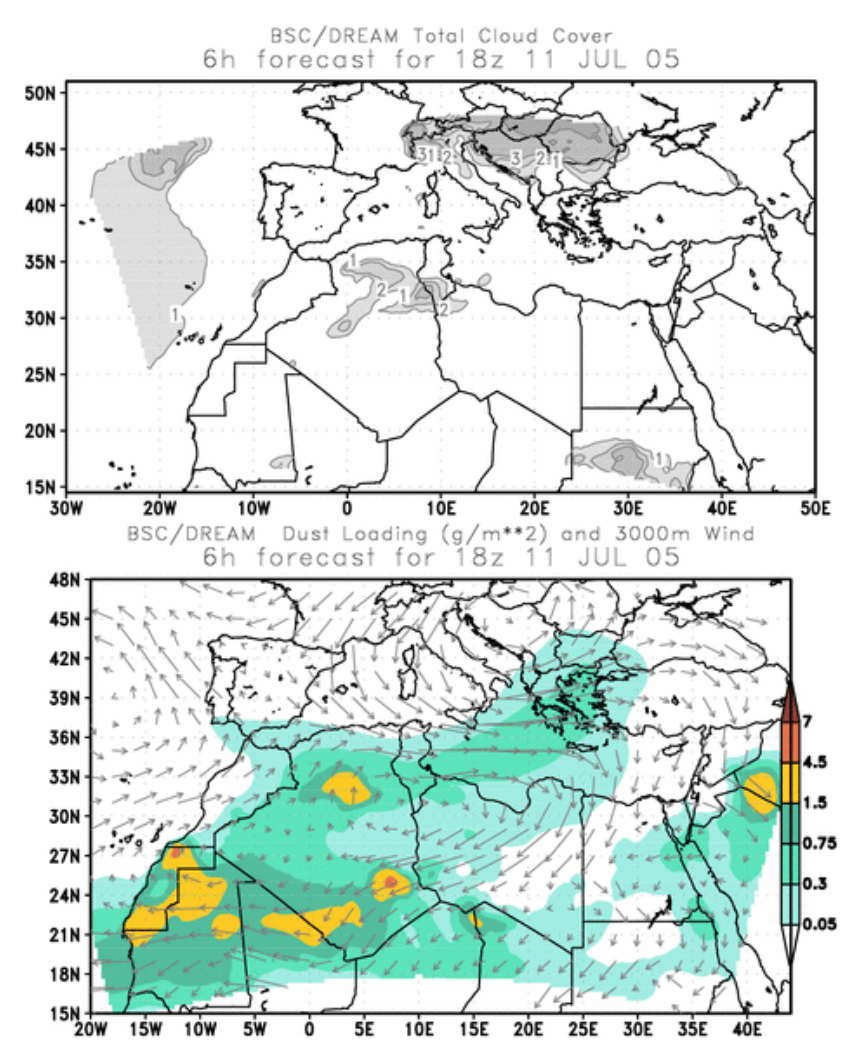

Fig. 3. Total cloud cover (relative units), dust load $\left(\mathrm{g} / \mathrm{m}^{2}\right)$ and wind vectors (at $3000 \mathrm{~m}$ ) over Mediterranean on 11 of July 2005 at 18:00 UTC, when dust aerosol was present over Athens, as estimated by the DREAM model.

backscatter profile over the retrieved PBL height (Matthias et al., 2004b). According to that paper, the annual cycle of the PBL height over Athens shows only a weak dependence on season. However, the highest value of the PBL can reach the value of $2.8 \mathrm{~km}$ height mainly during the month of August, while its mean value is of the order of $1.172 \pm 0.319 \mathrm{~km}$. In addition, under certain circumstances (less than about 5\% of the cases according to BSC/DREAM model) Saharan dust can markedly affect the lowermost levels of the atmosphere, and then the base of the dust aerosol layer is found near ground level. In our data analysis we have considered both possibilities.

On the other hand the top of the desert dust layer is located at an altitude at which the aerosol backscatter becomes zero within the experimental error. Knowing the base and the top of the dust layer, its thickness can be calculated. The center of mass is estimated by the calculation of the backscatter weighted altitude $\left(z_{c}\right)$ (Mona et al., 2006) given as follows, where $\beta$ represents the aerosol backscatter coefficient:

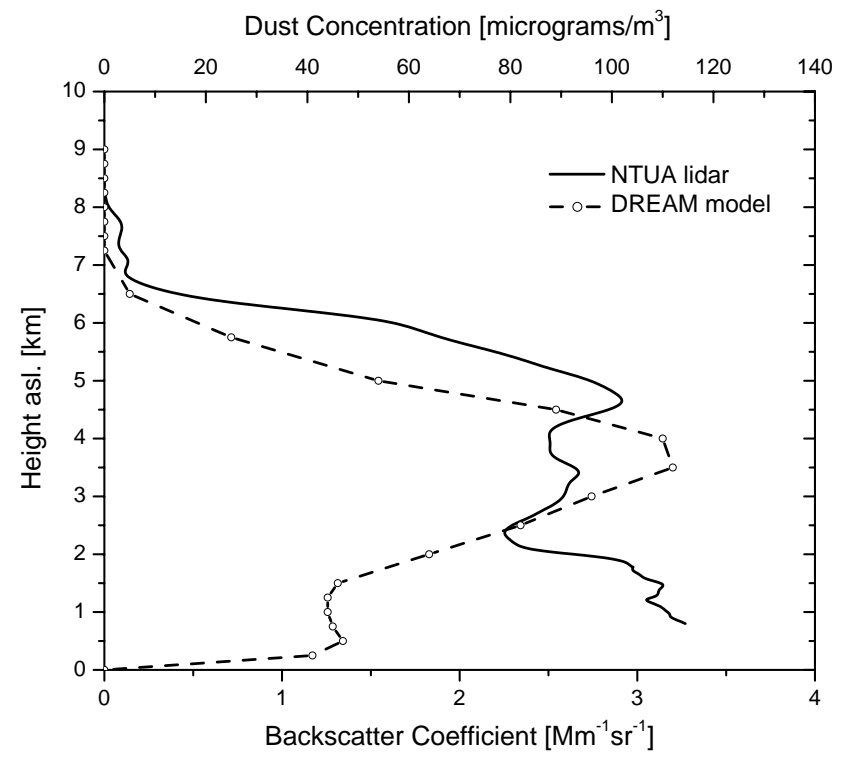

Fig. 4. Aerosol backscatter coefficient obtained by NTUA lidar at $532 \mathrm{~nm}$ on 11 of July 2005 at 18:00 UTC, along with the corresponding dust concentration profile estimated by the DREAM model.

$$
z_{c}=\frac{\int_{z_{b}}^{z_{t}} z \cdot \beta(z) d z}{\int_{z_{b}}^{z_{t}} \beta(z) d z}
$$

Therefore, the backscatter weighted altitude is an approximation of the centre of mass of the aerosol layer that exactly coincides with the true center of mass if both composition and size distribution of the particles are constant with altitude. Thus, the estimate of the center of mass gives us information about the altitude where the most relevant part of the aerosol load is located (Mona et al., 2006).

The methodology for the characterization of a strong dust episode and the dust layer selection for the calculation of the center of mass is described in Figs. 3 and 4. A typical example of Saharan dust cloud forecasted by the BSC/DREAM model on 11 July 2005 (18:00 UTC) is shown in Fig. 3. For the city of Athens, that day was a cloud-free day (Fig. 3 - upper part) with a high aerosol load $\left(0.75-1.5 \mathrm{~g} / \mathrm{m}^{2}\right)$ of dust particles transported from the western Saharan region to Greece (Fig. 3 - lower part). The corresponding dust concentration profile forecasted by BSC/DREAM is given in Fig. 4 (black continuous line). The aerosol backscatter vertical profile obtained by the NTUA lidar at $532 \mathrm{~nm}$ on the same day (18:00 UTC) shows the presence of a huge dust cloud (dust concentrations reached values of $110 \mu \mathrm{g} / \mathrm{m}^{3}$ ) ranging from the top of the PBL (around $2.5 \mathrm{~km}$ ) up to nearly $7 \mathrm{~km}$ height. Inside the PBL (i.e. below $2 \mathrm{~km}$ height, estimated by using the method proposed by Menut et al., 1999) the model shows only the dust profile and not the actual aerosol profile which 
Table 1. Height distribution of the mean, minimum and maximum values of desert dust altitude range parameters (base, top, thickness and center of mass) retrieved from lidar backscatter data obtained at $532 \mathrm{~nm}$ over Athens (January 2004-December 2006) in comparison with older data (May 2000-December 2002), as given by Papayannis et al. (2008).

\begin{tabular}{|c|c|c|c|c|c|c|c|c|}
\hline Period & $\begin{array}{c}\text { Base } \\
\text { Mean (m) }\end{array}$ & $\begin{array}{l}\text { Base Min, } \\
\text { Max (m) }\end{array}$ & $\begin{array}{c}\text { Top } \\
\text { Mean (m) }\end{array}$ & $\begin{array}{l}\text { Top Min, } \\
\text { Max (m) }\end{array}$ & $\begin{array}{l}\text { Thickness } \\
\text { Mean (m) }\end{array}$ & $\begin{array}{l}\text { Thickness Min, } \\
\text { Max (m) }\end{array}$ & $\begin{array}{l}\text { Center of mass } \\
\text { Mean (m) }\end{array}$ & $\begin{array}{l}\text { Center of mass } \\
\text { Min, Max (m) }\end{array}$ \\
\hline May 2000-Decem & 2100 & 1100,3000 & 4970 & 1900,8000 & 2154 & 500,4800 & 3570 & 1500,8500 \\
\hline January 2004-December 2006 & 1961 & 1202,3742 & 4647 & 2004,8005 & 2686 & 681,4865 & 2917 & 1608,5758 \\
\hline
\end{tabular}

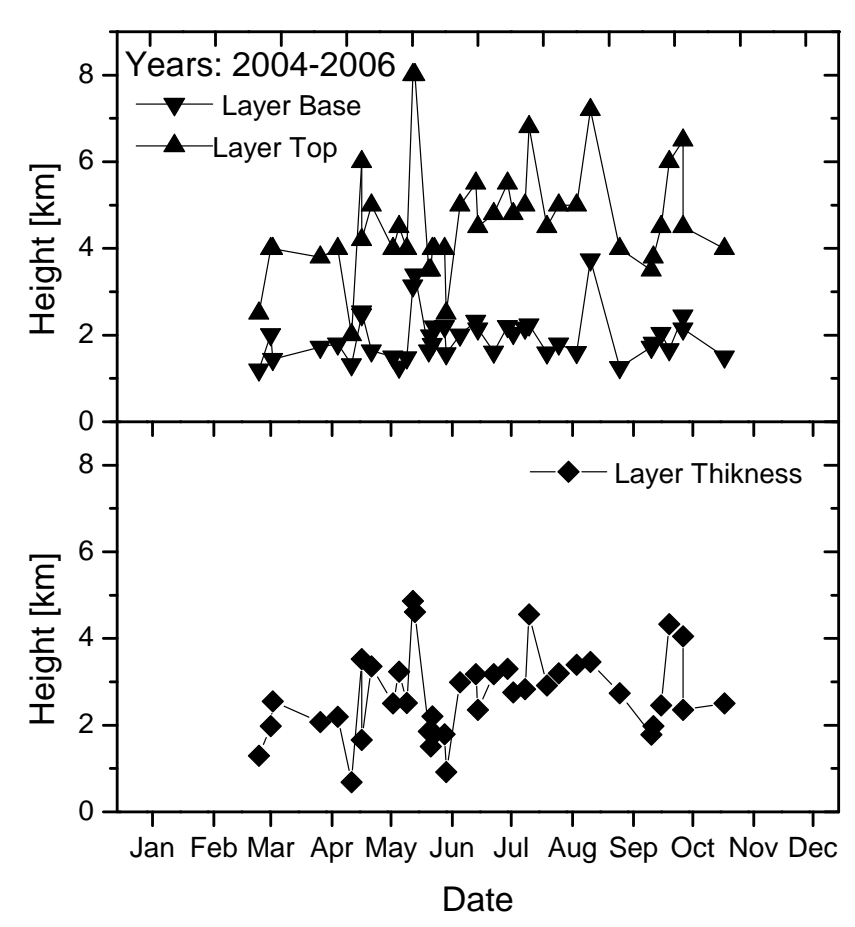

Fig. 5. Annual cycle of the base and top of the dust layer (upper part) and of the layer thickness (lower part) for the three-year period (January 2004-December 2006).

also contains aerosols emitted from local sources. For the case study of 11 July 2005 presented in Figs. 3 and 4, all the criteria adopted in this study for the characterization of a strong Saharan dust episode are fulfilled. BSC/DREAM concentrations reach high values and the model follows the dust vertical distribution as this was measured with lidar. Dust presence is evident both from the model and lidar data for the height range between 2.5 to $7 \mathrm{~km}$. From the profile comparison in Fig. 4 and the fact that the PBL for the time of measurement was found to be at $2.5 \mathrm{~km}$, we conclude that within the $2.5-7 \mathrm{~km}$ height range, only dust particles were present.

Following the above mentioned methodology, we calculated the base and top heights for each Saharan dust profile for our selected cases. Table 1 shows the mean, minimum

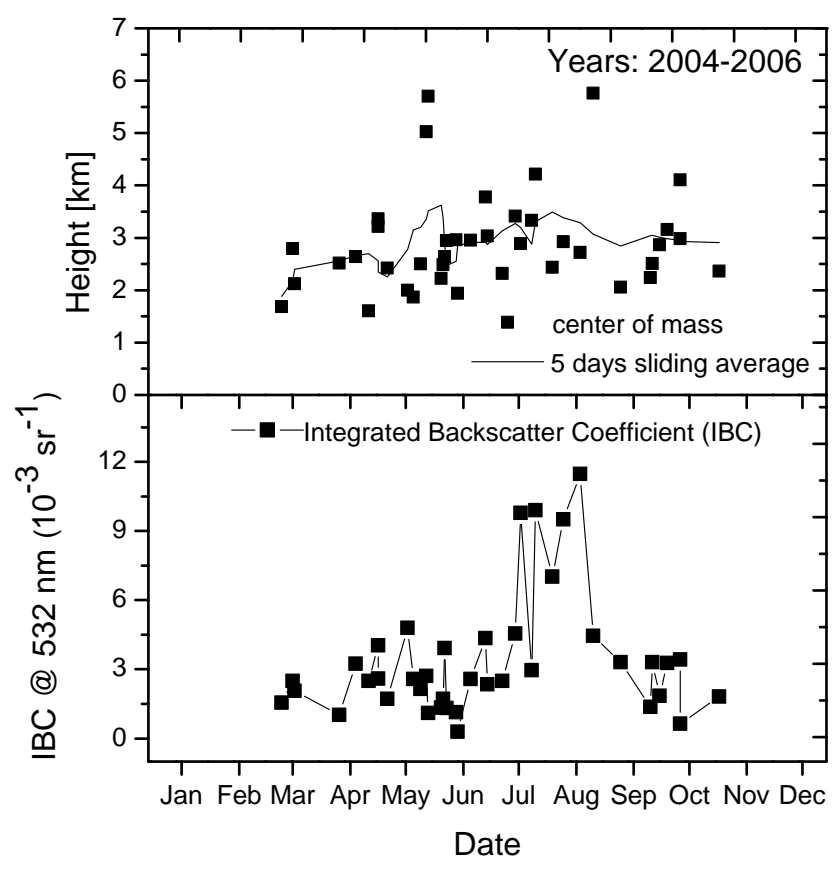

Fig. 6. Annual cycle of the backscatter weighted altitude of the desert dust layer $\left(z_{c}\right)$ (upper part) and of the integrated backscatter coefficient (IBC) (lower part) for the three-years period (January 2004-December 2006). The solid line in the upper figure is the 5-days sliding average.

and maximum values of desert dust altitude range parameters (base, top, thickness and center of mass), as retrieved from aerosol backscatter profiles obtained at $532 \mathrm{~nm}$ for the discussed period (January 2004-December 2006). In addition, for comparison reasons, we show the respective values for the period May 2000-December 2002, as retrieved from Papayannis et al. (2008). We can see that, for the discussed period (January 2004-December 2006), multiple aerosol dust layers of variable thickness $(680-4800 \mathrm{~m})$ were observed. The center of mass of these layers was located in altitudes between 1600 and $5800 \mathrm{~m}$. However, the mean thickness of the dust layer typically stayed around $2700 \mathrm{~m}$ and the corresponding mean center of mass was of the order of $2900 \mathrm{~m}$. The top of the dust layer ranged from 2000 to $8000 \mathrm{~m}$, with a mean value of the order of $4700 \mathrm{~m}$. On the 

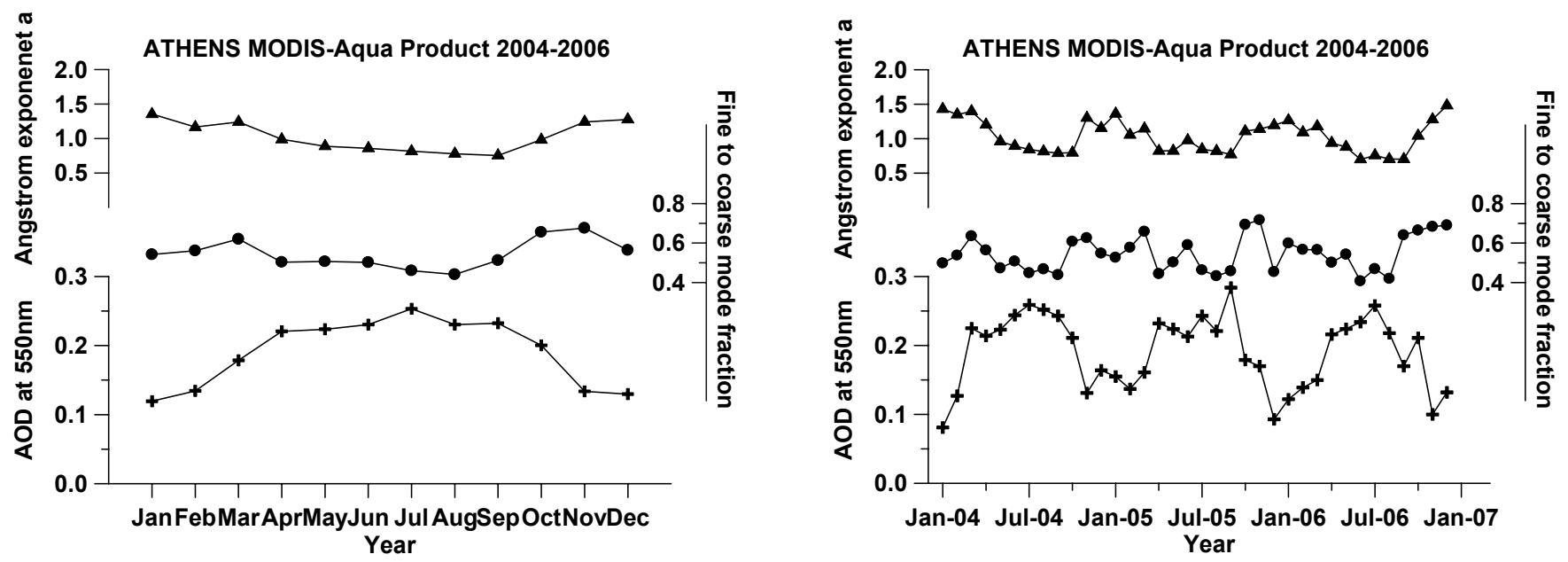

Fig. 7. Temporal evolution of the AE and AOD (left) and the corresponding monthly means of the AE, AOD and the fine to coarse mode fraction of aerosols (right). The data were obtained from MODIS over Athens for the three-year period (January 2004-December 2006).

other hand, the base of the dust layer typically stayed around $1960 \mathrm{~m}$, with values ranging from 1200 and $3740 \mathrm{~m}$. These findings, for most of these variables, are consistent (less than $8 \%$ difference is found) with the respective results given for the station of Athens by Papayannis et al. (2008) for the period May 2000-December 2002. The exception holds for the mean values of dust layer thickness and center of mass (differences of the order of $20-22 \%$ were found), as well as for the base (max value) and thickness (min value) of the dust layer, where differences of the order of $20-26 \%$ were observed.

Our results on the geometrical properties of the dust layers, namely the annual cycle of the base and top of the dust layer (upper part) and that of the dust layer thickness (lower part) for the three-year period (January 2004-December 2006) are presented analytically in Fig. 5, We see that May, mid July and mid-August are the three periods of the year where the highest dust layer tops (6-8 km height) are observed over Athens. Then mid-September and October also shows the highest values (around $6 \mathrm{~km}$ height) of the dust layer top, during the autumn period. On the other hand the dust layer base remains around $2 \mathrm{~km}$ height except during mid-May and mid-August when it reaches 3-4 km height. All these may be related to the stronger dust events which occur during this period over the area (Papayannis et al., 2008) and to the highest convective activity, mostly observed during the summer period (hottest period of the year). The temporal evolution of the dust layer thickness presented in the lower part of Fig. 5 shows a strong variability around a mean value of $2.7-2.8 \mathrm{~km}$ height (see also Table 1), which seems to be typical for the southern Mediterranean region (Mona et al., 2006). Again May, mid-July and mid-September are the periods of the year when the highest dust layer thicknesses are observed, which corresponds to the strongest dust activity and transport from the Sahara desert to the European continent (Mona et al., 2006; Papayannis et al., 2008).

In Fig. 6 (upper part) we present the annual cycle of the backscatter weighted altitude of the desert dust layer $\left(z_{c}\right)$ and in the lower part the integrated backscatter coefficient (IBC) for the three-years period (January 2004-December 2006), both retrieved from lidar backscatter data obtained at $532 \mathrm{~nm}$. The solid line in the upper figure is the 5-days sliding average. We observe an intense variability of the center of mass altitude during May and August, which are the months with the higher dust loadings, the stronger dust events and hence, in this period the stronger dust variability may occur ( $\mathrm{Pa}$ payannis et al., 2008). From the IBC annual variability we conclude that even if the occurrences of dust episodes are more often during spring, their intensity is higher on late summer. This finding is in agreement also with the study of Mona et al. (2006). In that study, the authors observed these maxima on optical depth at $355 \mathrm{~nm}$ over Italy mainly during late summer.

\subsection{Optical properties of the desert dust layer deter- mined from MODIS data}

The aerosol optical depth at $550 \mathrm{~nm}$ and the Angström exponent (AE) level-2 were obtained by MODIS, which the pixel spatial resolution over Athens was $10 \times 10 \mathrm{~km}$. Figure 7 (left) presents the temporal evolution of AOD and $\mathrm{AE}$ in the reported three-year period (January 2004-December 2006). The AOD values, which are higher than 0.3 , would correspond to aerosol dust loads, mostly connected with transport of dust from Africa to Athens. The maximum values which are of the order of 0.4-0.6 would correspond to intense dust outbreaks. Similar or even higher AOD values obtained by MODIS were also reported by Amiridis et al. (2009) and 
by Papayannis et al. (2005), again over Athens. The corresponding AE values, in the case of the Saharan dust outbreaks, range between 0.5 and 0.65 , indicating the presence of rather large particles. The corresponding monthly mean values of the $\mathrm{AE}, \mathrm{AOD}$ and the fine to coarse mode fraction of aerosols are given in Fig. 7 (right). We see again that during the spring, summer and early autumn months the AOD values present a peak from 0.2 to 0.27 (due to Saharan dust transport events), while the low AE values (around 1.0 ) and the fine to coarse mode fraction of aerosols (around $0.4)$ are mostly anti-correlated with the high AOD values. This, as explained previously, indicates the presence of rather large particles during the dust outbreaks. From Fig. 7 we see that these dust outbreaks take part mostly during the early spring-summer extending to the early autumn period as also reported by Papayannis et al. (2008) in the Southern Mediterranean Sea.

\section{Summary and conclusions}

The main aim of this work was to present a statistical analysis on the geometrical properties of Saharan dust vertical distribution over Athens, Greece, for a three year period lidar measurements (2004-2006). Springtime (April-May) is the period of the maximum dust event occurrence as indicated both from lidar and MODIS measurements. The lidar observations reported multiple aerosol dust layer and variable thickness (680-4800 m) appearances. The mean center of mass of these layers was approximately calculated at $2900 \mathrm{~m}$, with limited cases of events reaching altitudes over $5000 \mathrm{~m}$. In addition, mean layer thickness was found to be $2700 \mathrm{~m}$ and mean top of the layer at $4800 \mathrm{~m}$.

BSC/DREAM model aerosol dust climatology showed also predominant dust events for April and May periods. In addition, comparison of lidar retrieved backscatter coefficients and model calculated dust load showed fairly good agreement comparing the vertical profiles of dust aerosols. Trying to quantify the dust contribution to the Athens area, except from the obvious facts of its contribution to the spring months but also to the June-September period, we have to keep in mind that lidar dust analysis becomes difficult with the presence of clouds. Using only lidar or sun-photometric dust climatology leads to an underestimation of the dust effect especially in the winter months were the presence of clouds is more often. In the present study only 2 dust cases have been reported from lidar measurements during the winter period.

Aerosol observations during dust outbreaks obtained from MODIS showed that the AOD values at $550 \mathrm{~nm}$ ranged between 0.3-0.6, while the corresponding Angström exponent (AE) values were of the order of $0.5-0.65$, indicating the presence of rather large particles. Having in mind that AOD over Athens shows a maximum at July-August period, using MODIS AOD we observe the dust contribution as a sec- ondary peak for April-May months of all three years reported here. These periods are accompanied by small AE and minimum fine to coarse mode ratios indicating the presence of dust particles in the area.

Acknowledgements. The financial support for EARLINET (EARLINET-ASOS) by the European Commission under grant RICA-025991 is gratefully acknowledged. REM acknowledges the support of the PENED project. The PENED 2003 project is co-financed $80 \%$ of Public expenditure through EC - European Social Fund and 20\% of Public expenditure through Ministry of Development, General Secretariat of Research and development (Project 03-ED-169) and through private sector (Raymetrics SA.), under Measure 8.3 of OPERATIONAL PROGRAMME "COMPETITIVENESS" in the 3rd Community Support Programme. SK would like to acknowledge the Marie Curie Intra European Fellowship 'Validation of Aerosol Optical Properties and surface Irradiance measured from Ozone Monitoring Instrument on board of AURA satellite' VAP-OMI, AOR A/119693 - PIEF-GA2008-219908. We also acknowledge (REM and VA) the support by the NASA Grant: NNX06AF30G - Global Environmental Change-hazards and regional impacts, and support by the technical officers Don Anderson and Lucia Tsaoussi.

Topical Editor F. D'Andrea thanks two anonymous referees for their help in evaluating this paper.

\section{References}

Amiridis, V., Balis, D. S., Kazadzis, S., Bais, A., Giannakaki, E., Papayannis, A., and Zerefos, C.: Four-year aerosol observations with a Raman lidar at Thessaloniki, Greece, in the framework of European Aerosol Research Lidar Network (EARLINET), J. Geophys. Res., 110, D21203, doi:10.1029/2005JD006190, 2005.

Ansmann, A., Wandinger, U., Riebesell, M., Weitkamp, C., and Michaelis, W.: Independent measurements of extinction and backscatter profiles in cirrus clouds using a combined Raman elastic-backscatter lidar, Appl. Optics, 22, 2257-2264, 1992.

Ansmann, A., Wandinger U., Wiedensohler, A., and Leiterer, U.: Lindenberg Aerosol Characterization Experiment (LACE) 98: Overview, J. Geophys. Res., 107(D21), 8129, doi:10.1029/2000JD000233, 2002.

Balis, D., Amiridis, V., Nickovic, S., Papayannis, A., and Zerefos, C.: Optical properties of Saharan dust layers as detected by a Raman lidar at Thessaloniki, Greece, Geophys. Res. Lett., 31, L13104, doi:10.1029/2004GL019881, 2004.

Balis, D., Amiridis, V., Kazadzis, S., Papayannis, A., Tsaknakis, G., Tzortzakis, S., Kalivitis, N., Vrekoussis, M., Kanakidou, M., Mihalopoulos, N., Chourdakis, G., Nickovic, S., Pérez, C., Baldasano, J., and Drakakis, M.: Optical characteristics of desert dust over the East Mediterranean during summer: a case study, Ann. Geophys., 24, 807-821, 2006, http://www.ann-geophys.net/24/807/2006/.

Bellouin, N., Boucher, O., Haywood, J., and Reddy, M. S.: Global estimate of aerosol direct radiative forcing from satellite measurements, Nature, 438, 1138-1141, 2005.

Böckmann, C., Wandinger, U., Ansmann, A., et al.: Aerosol lidar intercomparison in the framework of the EARLINET project. 2. Aerosol backscatter algorithms, Appl. Optics, 43, 977-989, 2004. 
Bösenberg, J., Timm, R., and Wulfmeyer, V.: Study of retrieval algorithms for a backscatter lidar, Final Report, MPI Report No. 226, pp. 1-66, Hamburg, 1997.

Bösenberg, J., Linne, H., Matthias, V., et al.: A European aerosol research lidar network to establish an aerosol climatology, MPIReport 348, Max-Planck Inst. für Meteorology, Hamburg, Germany, 2003.

Chu, D. A., Kaufman, Y. J., Ichoku, C., Remer, L. A., Tanré D., and Holben, B. N.: Validation of MODIS aerosol optical depth retrieval over land, Geophys. Res. Lett., 29, 8007, doi:10.1029/2001GL013205, 2002.

Chu, D. A., Kaufman, Y. J., Zibordi, G., Chern, J. D., Mao, J., Li, C., and Holben, B. N.: Global monitoring of air pollution over land from the Earth Observing System-Terra Moderate Resolution Imaging Spectroradiometer (MODIS), J. Geophys. Res., 108(D21), 4661, doi:10.1029/2002JD003179, 2003.

Duce, R. A.: Sources, distribution and fluxes of mineral aerosols and their relationship to climate. Aerosol Forcing on Climate, edited by: Carlson, R. J. and Heintzenberg, J., Wiley, New York, 43-72, 1995.

Eck, T., Holben, B. N., Ward, D. E., et al.: Variability of biomass burning aerosol optical characteristics in southern Africa during the SAFARI 2000 dry season campaign and a comparison of single scattering albedo estimates from radiometric measurements, J. Geophys. Res., 108(D13), 8477, doi:10.1029/2002JD002321, 2003.

Engelstaedter, S. and Washington, R.: Temporal controls on global dust emissions: The role of surface gustiness, Geophys. Res. Lett., 34, L15805, doi:10.1029/2007GL029971, 2007.

Forster, P., Ramaswamy, V., Artaxo, P., Berntsen, T., Betts, R., Fahey, D.W., Haywood, J., Lean, J., Lowe, D.C., Myhre, G., Nganga, J., Prinn, R., Raga, G., Schulz, M., and Van Dorland, R.: Changes in Atmospheric Constituents and in Radiative Forcing, in: Climate Change 2007: The Physical Science Basis, contribution of Working Group I to the Fourth Assessment Report of the Intergovernmental Panel on Climate Change, edited by: Solomon, S., Qin, D., Manning, M., Chen, Z., Marquis, M., Averyt, K. B., Tignor, M., and Miller, H. L., Cambridge University Press, Cambridge, United Kingdom and New York, NY, USA, 2007.

Greed, G., Haywood, J. M., Milton, S., Keil, A., Christopher, S., Gupta, P., and Highwood, E. J.: Aerosol optical depths over North Africa: 2. Modeling and model validation, J. Geophys. Res., 113, D00C05, doi:10.1029/2007JD009457, 2008.

Hatzianastassiou, N., Matsoukas, C., Drakakis, E., Stackhouse Jr., P. W., Koepke, P., Fotiadi, A., Pavlakis, K. G., and Vardavas, I.: The direct effect of aerosols on solar radiation based on satellite observations, reanalysis datasets, and spectral aerosol optical properties from Global Aerosol Data Set (GADS), Atmos. Chem. Phys., 7, 2585-2599, 2007, http://www.atmos-chem-phys.net/7/2585/2007/.

Haywood, J. M., Pelon, J., Formenti, P., et al.: Overview of the Dust and Biomass-burning Experiment and African Monsoon Multidisciplinary Analysis Special Observing Period-0, J. Geophys. Res., 113, D00C17, doi:10.1029/2008JD010077, 2008.

Husar, R. B., Prospero, J. M., and Stowe, L. L.: Characterization of tropospheric aerosols over the oceans with the NOAA advanced very high resolution radiometer optical thiockness operational product, J. Geophys.Res., 102, 16889-16909, 1997.
Jickells, T. D., An, Z. S., Andersen, K. K., et al.: Global iron connections between desert dust, ocean biogeochemistry, and climate, Science, 308, 67-71, 2005.

Jiménez-Guerrero, P., Pérez, C., Jobra, O., and Baldasano, J.: Contribution of Saharan dust in an ingrated air quality system and its on-line assessment, Geophys. Res. Lett., 35, L03814, doi:10.1029/2007GL031580, 2008.

Johnson, B. T., Heese, B., McFarlane, S. A., Chazette, P., Jones, A., and Bellouin, N.: Vertical distribution and radiative effects of mineral dust and biomass burning aerosol over West Africa during DABEX, J. Geophys. Res., 113, D00C12, doi:10.1029/2008JD009848, 2008.

Kaskaoutis, G. G., Kosmopoulos, P., Kambezidis, H. D., and Nastos, P. T.: Aerosol climatology and discrimination of different types over Athens, Greece, based on MODIS data, Atmos. Environ. 41, 7315-7329, 2007.

Kaufman, Y. and Tanré, D.: Algorithms for remote sensing of tropospheric aerosol from MODIS. NASA MODIS Algorithm Theoretical Basis Document, Goddard Space Flight Center, pp. 85, 1998.

Kaufman, Y. J., Tanré, D., Holben, B. N., Mattoo, S., Remer, L. A., Eck, T. F., Vaughan, J., and Chatenet, B.: Aerosol radiative impact on spectral solar flux at the surface, derived from principalplane sky measurements, J. Atmos. Sciences, 59, 635-646, 2002.

Kaufman, Y. J., Koren, I., Remer, L. A., Tanré, D., Ginoux, P., and Fan, S.: Dust transport and deposition observed from the Terra-Moderate Resolution Imaging Spectroradiometer (MODIS) spacecraft over the Atlantic Ocean, J. Geophys. Res., 110, D10S12, doi:10.1029/2003JD004436, 2005.

Kinne, S., Schulz, M., Textor, C., et al.: An AeroCom initial assessment - optical properties in aerosol component modules of global models, Atmos. Chem. Phys., 6, 1815-1834, 2006, http://www.atmos-chem-phys.net/6/1815/2006/.

Klett, J.: Lidar inversion with variable backscatter to extinction ratios, Appl. Optics, 24, 1638-1643, 1985.

Laurent, B., Marticorena, B., Bergametti, G., Léon, J. F., and Mahowald, N. M.: Modeling mineral dust emissions from the Sahara desert using new surface properties and soil database, J. Geophys. Res., 113, D14218, doi:10.1029/2007JD009484, 2008.

Levin, Z., Ganor, E., and Gladstein, V.: The effects of desert particles on with sulphate on rain formation in the Eastern Mediterranean, J. Appl. Meteor., 35, 1511-1523, 1996.

Marticorena, B., Bergametti, G., Aumont, B., Callot, Y., N'Doumé, C., and Legrand, M.: Modeling the atmospheric dust cycle: 2. Simulation of Saharan dust sources, J. Geophys. Res., 102, 4387-4404, 1997.

Matthias, V., Freudenthaler, V., Amodeo, A., et al.: Aerosol lidar intercomparison in the framework of the EARLINET project. 1. Instruments, Appl. Optics, 43, 961-976, 2004a.

Matthias, V., Balis, D., Boesenberg, J., et al.: Vertical aerosol distribution over Europe: Statistical analysis of Raman lidar data from 10 European Aerosol Research Lidar Network (EARLINET) stations, J. Geophys. Res., 109, D18201, doi:10.1029/2004JD004638, 2004b.

Mattis, I., Ansmann, A., Müller, D., Wandinger, U., and Althausen, D.: Dual-wavelength Raman lidar observations of the extinctionto-backscatter ratio of Saharan dust, Geophys. Res. Lett., 29, 1306, doi:10.1029/2002GL014721, 2002.

Mattis, I., Müller, D., Ansmann, A., Wandinger, U., Preissler, 
J., Seifert, P., and Tesche, M.: Ten years of multiwavelength Raman lidar aerosol layers over central Europe: Geometrical properties and annual cycle, J. Geophys. Res., 113, D20202, doi:10.1029/2007JD009636, 2008.

Menut, L., Flamant, C. Pelon, J., and Flamant, P. H.: Urban boundary layer height determination from lidar measurements over the Paris area, Appl. Optics, 38, 945-954, 1999.

Menut, L., Forêt, G., and Bergametti, G.: Sensitivity of mineral dust concentrations to the model size distribution accuracy, J. Geophys. Res., 112, D10210, doi:10.1029/2006JD007766, 2007.

Menut, L.: Sensitivity of hourly Saharan dust emissions to NCEP and ECMWF modeled wind speed, J. Geophys. Res., 113, D16201, doi:10.1029/2007JD009522, 2008.

Misra, A., Jayaraman, A., and Ganguly, D.: Validation of MODIS derived aerosol optical depth over Western India, J. Geophys. Res., 113, D04203, doi:10.1029/2007JD009075, 2008.

Molesworth, A., Cuevas, E., Morse, A., Herman, J. R., Thomson, M. C.: Dust clouds and spread of infection, The Lancet, 359, 81-82, 2002.

Mona, L., Amodeo, A., Pandolfi, M., and Pappalardo, G.: Saharan dust intrusions in the Mediterranean area: Three years of Raman lidar measurements, J. Geophys. Res., 111, D16203, doi:10.1029/2005JD006569, 2006.

Nickovic, S., Kallos, G., Papadopoulos, A., and Kakaliagou, O.: A model for prediction of desert dust cycle in the atmosphere, J. Geophys. Res., 106, 18113-18129, 2001.

Papayannis, A., Balis, D., Amiridis, V., Chourdakis, G., Tsaknakis, G., Zerefos, C., Castanho, A. D. A., Nickovic, S., Kazadzis, S., and Grabowski, J.: Measurements of Saharan dust aerosols over the Eastern Mediterranean using elastic backscatter-Raman lidar, spectrophotometric and satellite observations in the frame of the EARLINET project, Atmos. Chem. Phys., 5, 2065-2079, 2005, http://www.atmos-chem-phys.net/5/2065/2005/.

Papayannis, A., Zhang, H. Q., Amiridis, V., et al.: Extraordinary dust event over Beijing, China, during April 2006: Lidar, Sun photometric, satellite observations and model validation, Geophys. Res. Lett., 34, L07806, doi:10.1029/2006GL029125, 2007a.

Papayannis, A., Mamouri, R. E., Chourdakis, G., Georgoussis, G., V. Amiridis, Paronis, D., Tsaknakis, G., and Avdikos, G.: Retrieval of the optical properties of tropospheric aerosols over Athens, Greece combining a 6-wavelength Raman-lidar and the CALIPSO VIS-NIR lidar system: Case-study analysis of a Saharan dust intrusion over the Eastern Mediterranean, J. Optoelec. Adv. Materials, 9, 3514-3517, 2007b.
Papayannis, A., Amiridis, V., Mona, L., et al.: Systematic lidar observations of Saharan dust over Europe in the frame of EARLINET (2000-2002 J. Geophys. Res., 113, D10204, doi:10.1029/2007JD009028, 2008.

Pappalardo, G., Amodeo, A., Pandolfi, M., et al.: Aerosol lidar intercomparison in the framework of the EARLINET project. 3. Raman lidar algorithm for aerosol extinction, backscatter and lidar ration, Appl. Optics, 43, 5370-5385, 2004.

Pérez C., Nickovic S., Pejanovic, G., Baldasano, J. M., and Özsoy, E.: Interactive dust-radiation modeling: A step to improve weather forecasts, J. Geophys. Res., 111, D16206, doi:10.1029/2005JD006717, 2006.

Prasad, A. K. and Singh, R. P.: Validation of MODIS Terra, AIRS, NCEP/DOE AMIP-II Reanalysis-2, and AERONET Sun photometer derived integrated precipitable water vapor using ground-based GPS receivers over India, J. Geophys. Res., 114, D05107, doi:10.1029/2008JD011230.

Prospero, J. M.: Long-term measurements of the transport of African mineral dust to the southeastern United States: Implications for regional air quality, J. Geophys. Res., 104, 1591715927, 1999.

Prospero, J. M., Ginoux, P., Torres, O.,. Nicholson, S. E., and Gill, T. E.: Environmental characterization of global sources of atmospheric soil dust identified with the Nimbus 7 Total Ozone Mapping Spectrometer (TOMS) absorbing aerosol products, Rev. Geophys., 40(1), 1002, doi:10.1029/2000RG000095, 2002.

Rosenfeld, D., Rudich, Y., and Lahav, R.: Desert dust suppressing precipitation: A possible desertification feedback loop, Proc. Natl. Acad. Sci. USA, 98, 5975-5980, 2001.

Sokolik, I. N. and Toon, O. B.: Incorporation of mineralogical composition into models of the radiative properties of mineral aerosol from UV to IR wavelengths, J. Geophys. Res.-Atmos., 104(D8), 9423-9444, 1999.

Sultan, B., Labadi, K., Guegan, J. F., and Janicot, S.: Climate drives the meningitis epidemics onset in West Africa, Pub. Lib. Sci. Med., 2, 43-49, 2005.

Tegen, I.: Modeling the mineral dust aerosol cycle in the climate system, Quat. Sci. Rev., 22, 1821-1834, 2003.

Teller, A. and Levin, Z.: The effects of aerosols on precipitation and dimensions of subtropical clouds: a sensitivity study using a numerical cloud model, Atmos. Chem. Phys., 6, 67-80, 2006, http://www.atmos-chem-phys.net/6/67/2006/. 